\title{
Eşdüzey Kavşak Düzenleme Projelerinde Bir Algoritma Önerisi: Yalova İli Örneği
}

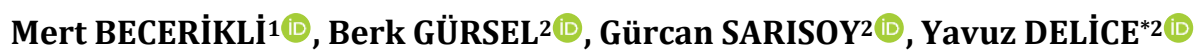 \\ ${ }^{1}$ Yalova Üniversitesi, Lisansüstü Eğitim Enstitüsü, Ulaştırma ve Lojistik Mühendisliği, 77200, Yalova, Türkiye \\ 2Yalova Üniversitesi, Mühendislik Fakültesi, Ulaştırma Mühendisliği Bölümü, 77200, Yalova, Türkiye
}

(Alınış / Received: 20.05.2021, Kabul / Accepted: 19.10.2021, Online Yayınlanma / Published Online: 25.12.2021)

\author{
Anahtar Kelimeler \\ Eşdüzey kavşak, \\ Simülasyon, \\ Mikro-simülasyon, \\ Sinyal optimizasyonu, \\ Hizmet düzeyi, \\ Ortalama gecikme
}

\begin{abstract}
Özet: Ulaştırma sektöründeki talepleri karşılamak adına sürekli gelişen teknolojik yöntemlerin kullanılmasıyla ulaşımdaki sorunları çözmek ve ulaşımı en faydalı hale getirmek amaçlanmaktadır. Buna göre, mikro-simülasyon programları kavşak düzenlemelerinde kullanılan araçların başında gelmektedir. Mikro-simülasyon programlarının kullanılması gerçek dünyada meydana gelen durumların gerçeğe çok yakın şekilde uyarlanmasına ve insan emeğinden zaman tasarrufuna, ekonomik anlamda kazançtan, kazaların önlenmesine kadar birçok konuda katkı sağlamaktadır. Çalışmanın özgün tarafı mikro-simülasyon programları ile eșdüzey kavşak düzenleme sürecinin geliştirilen iş akış şemasına göre yapılmasıdır. Bu bağlamda, saha çalışması için Yalova ilindeki bir eşdüzey kavşak seçilerek iş akış şeması test edilmiştir. Çalışmada verilen iki öneriden daha iyi olan seçeneğin mikrosimülasyon sonuçlarına göre; ortalama gecikme süresinde $\% 84$, ortalama hızda $\% 58$, ortalama kuyruk uzunluğunda \%93, zararlı gaz salınımlarında ve yakıt tüketiminde \%58 oranında iyileşme elde edilmiştir. Bu doğrultuda, eşdüzey kavşak düzenleme önerilerinde mikro-simülasyon programlarının kullanılmasının verimliliği saha çalışması ile gösterilmiş, bu hususta ilerleyen çalışmaları destekleyecek çıktılar sunulmuştur.
\end{abstract}

\section{An Algorithm Approach for Intersection Design Projects: The Case of Yalova Province}

\section{Keywords}

Intersection,

Simulation,

Micro-simulation,

Signal optimization,

Level of service,

Average delay

\begin{abstract}
In order to meet the demands in the field of transportation, it is aimed to solve the problems in transportation and to make transportation most beneficial by using constantly developing technological methods. Accordingly, micro-simulation programs are one of the main tools used in intersection designs. The usage of microsimulation programs enables real-world situations to be modeled very close to reality. This contributes to many issues, from human labor to time saving, from economic benefit to accident prevention. One of the original aspects of the study is that the process of designing intersections with micro-simulation programs is carried out according to the developed workflow diagram. In this context, the workflow diagram was tested by selecting an intersection in Yalova province for the field study. According to the micro-simulation results of the option that is better than the two alternatives given the study, improvements were achieved by $84 \%$ in average delay time, $58 \%$ in average speed, $93 \%$ in average queue length, $58 \%$ in fuel consumption and harmful gas emissions. In this direction, the efficiency of using micro-simulation programs in intersection design alternatives is demonstrated through fieldwork, and outputs are presented to support future studies in this issue.
\end{abstract}

\section{Giriş}

Son yıllarda Türkiye'de ulaştırma altyapısının gelişmesi ve artan nüfus ile otomobil sahipliğinde önemli bir yükseliş gözlenmiștir. 2021 yllı Türkiye İstatistik Kurumundan (TÜIK) alınan verilere göre Türkiye'deki trafiğe kayıtlı taşıt sayısı son 10 yılda
\%52 artmıştır [1]. Bu artış ile trafik sorunlarının da doğru orantılı bir şekilde arttığı görülmektedir. Farklı ulaşım türlerine olan talebin her geçen gün artması birtakım sorunları beraberinde getirmektedir. $\mathrm{Bu}$ sorunların başında trafik tıkanıklığı gelmektedir. Trafik tıkanıklığı sonucu seyahat sürelerinin artması insanların yaşam kalitesinde negatif yönde bir etki 
bırakmaktadır. Diğer önemli sorunlar arasında ekonomik anlamda yakıt tüketimindeki yükseliş ve çevre açısından doğaya salınan zararlı gazlardaki artış yer almaktadır [2].

Günümüzde ulaşım sorunlarını ortadan kaldırmak ya da olumsuz etkilerini en aza indirmeyi sağlamak için birçok çalışma yapılmaktadır ve ulaşımı en faydalı formuna getirmek hedeflenmektedir. Bu kimi zaman klasik yöntemlerle kimi zaman da daha verimli sonuçlar alınan teknolojik yöntemlerle gerçekleştirilmektedir. Ulaşım planlamasında kullanılan makro ve mikro-simülasyon programları bu teknolojik yöntemlerin başında gelmektedir. Trafik simülasyonları trafik ağlarının ve sistemlerinin planlanması ve tasarımında kullanılan yaygın yöntemlerdendir [3]. Mikro-simülasyon programlarının sağladığı ekonomik faydalar ve zaman tasarruflarının yanı sıra risksiz ve verimli olması bu programların kullanımını her geçen gün artırmaktadır. Mikro-simülasyon programlarının sağladığı bu avantajlardan dolayı alternatif çözümler etkili bir şekilde analiz edilebilmektedir [4].

Kentsel ulaşım ağı ve sistemlerinin modellenmesi gibi çeşitli planlama unsurlarında kullanılan simülasyon programları, ulaşımın kilit noktaları olan kavşak düzenlemelerinde de sıklıkla kullanılmaktadır [5]. Bir kavşağın düzenleme sonrası performansının analizi, gerçek hayatta düzenleme yapılmadan simülasyon programları ile risksiz ve güvenilir bir şekilde elde edilebilmektedir. Karşılaşlabilecek olası sorunlar ve olumsuz durumlar önceden tespit edilerek bunlara uygun çözüm önerileri geliştirilebilmektedir.

Günümüzde kavşak düzenlemeleri yapılırken mikrosimülasyon programları sıklıkla kullanılmakta ve bu programlar ile kavşak düzenleme önerisi geliştirilirken farklı yollar izlenebilmektedir. $\mathrm{Bu}$ çalışma kapsamında, mikro-simülasyon programı ile eşdüzey kavşak düzenlemesi sırasında takip edilmesi gereken bir iş akış şeması önerilmiştir. Buna göre, önerilen iş akış şemasının seçilen eşdüzey kavşak üzerinde denenerek işlevselliğinin kanıtlanması amaçlanmıştır. Bu doğrultuda, Yalova ilinde belirlenen Orman İşletme kavşağının performans analizleri yapılmıştır. Kavşak sayım verileri hafta içinde sabah, öğle ve akşam zirve saatlerinde toplanmıştır. Kavşağın mevcut durumdaki geometrisi modellenerek gözlenen verilerden elde edilen zirve saat taşıt hacimleri mikro-simülasyon programına girilmiştir. Simülasyonun gerçeği en doğru şekilde yansıtması ve daha doğru sonuçlar vermesi için model üzerinde kalibrasyon çalışmaları yapılmıştır. Analiz sonuçlarında kavşağın performansını etkileyen ortalama gecikme, ortalama hız, ortalama kuyruk uzunluğu, zararlı gaz salınımı ve yakıt tüketimi gibi parametrelerin iyileştirilmesi ve kavşağın hizmet düzeyini yükseltmek hedeflenmektedir. $\mathrm{Bu}$ amaçla, mevcut kavşak türünün korunarak sinyal optimizasyonunun yapıldığı ve mevcut kavşak türünün değiștirilerek dönel kavşak tasarımının uygulandığı iki farklı öneri geliştirilmiştir. Bu önerilerin geliștirilmesinde PTV Vissim mikrosimülasyon programı ve PTV Vistro sinyal optimizasyon programı kullanılmış ve önerilerin analiz sonuçları karşılaştırılmıştır.

\subsection{Literatür araştırması}

Kavşakların mevcut durum analizinde ve düzenleme önerilerinde mikro-simülasyon ve sinyal optimizasyon programlarının kullanıldı̆̆ı birçok çalışma görülmüştür. Konu ile ilgili bazı çalışmalara ait bilgiler kronolojik sıraya göre verilmiştir.

Konya ilinde 2012 yılında yapılan çalıșmada trafik yoğunluğu yüksek olan üç kavşak üzerinde incelemelerde bulunulmuştur. Bu üç kavşağın isimleri sırasıyla Kule, Nalçacı-Sille ve Kabataş sinyalize kavşaklarıdır. Kavşakların mevcut durum analizleri için video kamera tekniği ile kavşaklarda çekim alınarak trafik sayımları yapılmıștır. Akım değerleri Sidra mikro-simülasyon programına girilerek kavşakların mevcut durumu analiz edilmiştir. Analizler sonucu tespit edilen sorunları gidermek, gecikmeleri azaltmak ve kapasiteyi artırmak amacıyla optimum devre süreleri önerilmiştir. Buna göre önerilerle, her üç kavşakta da gecikme süresi ve doygunluk derecesi azalırken kapasite artmıştır. Kule kavşağı bazında mevcut duruma göre ortalama gecikme süreleri $\% 35$ ve doygunluk derecelerinin $\% 20$ azaldığı, kapasitenin ise \%25 arttığı gözlenmiştir [6]. Bu çalışma, sinyal optimizasyonu yapılırken teknolojik yöntemler kullanılmasının kavşak düzenlemeleri için önemli olduğunu göstermektedir.

Zonguldak ilinde 2017 yılında trafik yoğunluğunun yüksek olduğu 100. Yıl Şehirlerarası Otobüs Terminali kavşağında yapılan çalışmada sinyal süresi kaynaklı taşıt beklemelerinin çevreye salınan zararlı gaz emisyonunu nasıl etkilediği irdelenmiştir. Bu amaçla, sabah zirve saatte video çekim ile kavşak görüntüsü kaydedilerek trafik akım değerleri saptanmıștır. Bu trafik akım değerleri Sidra Intersection mikrosimülasyon programına girilerek mevcut durum sonuçları alınmıştır. Mevcut durumdaki değerleri iyileştirmek için kavşağın sinyal süreleri için optimum süreler hesaplanmıştır. Yeni sinyal süreleri, mikrosimülasyon programında kavşak yeniden modellenerek analiz edilmiştir. Analiz sonuçlarına göre tüketilen yakıt miktarında \%22 oranında bir azalma olduğu görülmüștür. Doğaya salınan zararlı gaz emisyonlarında ( $\mathrm{CO}$ ve NOx) ise sirasıyla \%35 ve \%12 oranlarında azalma olduğu belirlenmiştir [7].

2017 yılında Ürdün'ün Amman ilinde bulunan şehrin önemli sinyalize kavşaklarından biri olan Tabarbour sinyalize kavşağında oluşan uzun taşıt kuyrukları, taşıt gecikmeleri ve doğaya salınan zararlı gaz emisyonları gibi sorunları çözmek için bir çalışma yapılmıştır. Bu çalışmada Synchro sinyal optimizasyon 
ve PTV Vissim mikro-simülasyon programları kullanılmıştır. Kavşağa uygulanmak istenen geometrik tasarım mikro-simülasyon programında modellenmiş, kavşağın sinyal süreleri ise sinyal optimizasyon programı kullanılarak belirlenmiştir. Önerilen tasarım ile kavşağın mevcut durumu mikrosimülasyon programında karşılaştırılarak analiz edilmiştir. Analiz sonuçlarına göre ortalama gecikmenin \%87 ve maksimum kuyruk uzunluğunun \%97 oranında azaldığı gözlenmiştir. Kavşak hizmet düzeyinin ise F'den C'ye yükseldiği belirtilmiştir [8]. Çalışmada hem mikro-simülasyon programının hem de sinyal optimizasyon programının kullanılması ve çözüm önerileri üretilmesi ulaşıma teknolojik yöntemlerin sağlayabileceği faydanın somut kanıtlarından biridir.

Erzurum ilinde 2018 yılında yapılan bir çalışmada Erzurum-Bingöl devlet yolu üzerinde, Atatürk Üniversitesi kampüsünü bu yola bağlayan noktada planlanan bir kavşağın mevcut durum analizleri, PTV Vissim mikro-simülasyon programı kullanılarak yapılmıştır. Karşılaşılan sorunlara yönelik geliştirilen çözüm önerileri de bu program üzerinden irdelenmiştir. Çalışmada kavşaktaki gecikme süreleri, kuyruk uzunlukları, yakıt tüketimleri ve çevreye verilen zararlı gaz emisyonları gibi parametreler mevcut ile öneri durumlar arasında karşılaştırılmıştır. Mikro-simülasyon programından alınan sonuçlara göre gecikme süresinde $\% 35$, kuyruk uzunluğunda $\% 83$ ve zararlı gaz salınımında \%23 oranlarında azalma gözlenmiştir [9].

2018 yılında yapılan bir çalışmada Denizli ilinde bulunan kentin en büyük dönel kavşaklarından biri olan Albayrak kavşağı ve yaklaşım kolunda bulunan Emniyet kavşağı irdelenmiştir. Çalışmanın amacı, kavşakların mevcut durumdaki sorunlarını belirleyip bu sorunları gidererek kavşağın performansını artıracak çözüm önerileri sunmaktır. Trafik sayımları yapılan kavşakların mevcut durumu, PTV Vissim mikro-simülasyon programında analiz edilmiștir. Mikro-simülasyon programında analizleri yapılan Emniyet kavşağına üç çözüm önerisi geliştirilmiştir. Sinyal sürelerinin düzenlenmesi ve optimizasyonunda TRANSYT-7F sinyal optimizasyon programı kullanılmıştır. Geliştirilen çözüm önerileri 4 fazlı öneri, 3 fazlı öneri ve dönel kavşak, mevcut durum ile PTV Vissim mikro-simülasyon programı kullanılarak karşılaştırılmıştır. Analiz sonuçlarına göre en fazla iyileşme dönel kavşak tasarımında alınmıştır. Çalışmanın diğer bölümünde Albayrak kavşağının dönel kavşak yerine sinyalize kavşak olarak işletilmesi önerilmiştir [10]. Bu çalışmada geometrik düzenleme ve sinyal optimizasyonu içeren çözüm önerileri geliștirilip birbirleriyle kıyaslanmıștır.

2018 yılında Malezya'nın George Town şehrinde yapılan çalışmada trafik sıkışıklığının en yüksek olduğu iki kavşak ele alınmıştır. Çalışmanın amacı kavşaklardaki trafik tıkanıklığını çözmek için ilk kavşağa uygulanması planlanan dönel kavşak tasarımının iki kavşağı da nasıl etkileyeceğinin saptanmasıdır. Çalışmada her iki kavşağın mevcut durum modeli ve analizi için PTV Vissim mikrosimülasyon programı kullanılmıştır. Sonrasında, dönel kavşak tasarımı uygulaması ile kavşaklar tekrar mikro-simülasyon programında modellenerek analiz edilmiştir. İlk kavşağa uygulanan dönel kavşak tasarımı kavşaktaki ortalama gecikmeyi \%98 oranında azaltmış, hizmet düzeyini ise $\mathrm{F}^{\prime}$ den A'ya çekmiştir. İkinci kavşakta ise ortalama gecikme \%76 azalmış, hizmet düzeyi de E'den A'ya yükselmiştir [11].

2019 yllında Irak'ın başkenti olan Bağdat'ın kuzeydoğusundaki Al-Fallah kavşağında yaşanan trafik tıkanıklığına çözüm bulabilmek için bir çalışma yapılmıştır. Kavşağın mevcut durumdaki gecikme sürelerinin ve hizmet düzeyinin belirlenmesinde Synchro sinyal optimizasyon programı kullanılmıştır. Analizler sonucu ortaya çıkan performans değerlerini iyileştirmek için geometrik düzenleme önerilmiş ve bu öneri aynı program üzerinde incelenmiştir. Mevcut durum ile öneri karşılaştırıldığında ortalama gecikmenin \%87 oranında azaldığı hizmet düzeyinin ise F'den D'ye yükseldiği görülmüştür [12]. Bu çalışmada gelecek planlaması çerçevesinde, öneri projede kullanılan taşıt hacimleri hedef yıla göre artırılmış ve bu doğrultuda kavşak geometrisinde önemli düzenlemeler yapılmıștır.

Endonezya'da 2019 yılında yapılan çalıșmada, Yogyakarta şehrinde bulunan trafik sıkışıklığının yoğun olduğu Imogiri Timur ve Wirosaban yollarının kesişiminde bulunan kavşak ele alınmıştır. Kavşak mevcut durumda sinyalizasyon olmadan işletilmektedir ve çalışmanın amacı kavşağı sinyalize kavşağa dönüştürerek mevcut durumla karşılaştırmaktır. Kavşağı sinyalize kavşağa dönüştürürken üç farklı çözüm önerisi sunulmuş her bir öneri PTV Vissim mikro-simülasyon programında modellenerek analiz sonuçları alınmıştır. Buna göre, en iyi sonucu veren öneri mevcut durumdaki ortalama kuyruk uzunluğunu \%16, maksimum kuyruk uzunluğunu ise \%7 oranlarında azaltmıştır. Kavşağın hizmet düzeyi D'den C'ye yükselmiştir [13].

Erzurum ilinde 2020 yılında yapılan bir çalışmada AIMSUN mikro-simülasyon programı kullanılarak kent içi kavşakların modellenmesi konusu ele alınmıştır. Çalışmada ele alınan Tebrizkapı kavşağı, Erzurum ilinin en işlek noktası olan Cumhuriyet caddesi ve Kars Kapı caddesinde bulunan trafiğin en yoğun olduğu kavşaklardan birisidir. Mikrosimülasyon programı kullanılarak irdelenen bu kavşakta gecikme sürelerini azaltarak kavşağın performansını artırmak amaçlanmıştır. Mevcut durumdaki sorunlara çözüm önerisi olarak kavşak türünün değiştiği iki farklı senaryo sunulmuştur. İlk senaryo olan modern dönel kavşak tasarımı mikrosimülasyon programında modellenmiş ve analizleri 
yapılmıştır. Analiz sonuçlarına göre kavşaktaki gecikme sürelerinde \%78'e varan bir azalma görülmüștür. İkinci senaryo olarak farklı düzey kavşak önerisi sunulmuş ve mikro-simülasyon programında modellenerek analiz edilmiştir. Analiz sonuçlarına göre mevcut durumdaki gecikme sürelerinde $\% 88$ oranında bir iyileşme görülmüştür. Çalışmada, farklı düzey kavşağın performans sonuçları daha iyi olmasına karşın modern dönel kavşak ekonomik açıdan da değerlendirildiğinde daha uygun bulunmuștur [14].

2020 yılında Slovakya'nın Košice şehrinde yapılan çalışmada mikro-simülasyon programı kullanılarak bir kavşağın performansını artırmak hedeflenmiştir. Bu çalışmada PTV Vissim mikro-simülasyon programı kullanılmıştır. Kavşağın mevcut durumu ve öneri projeleri bu mikro-simülasyon programında modellenerek performans analizleri gerçekleştirilmiş ve çıktılar karşılaştırılmıştır. Sonuçlara göre geliştirilen öneri ile ortalama kuyruk uzunluğunda \%75, maksimum kuyruk uzunluğunda \%30 azalmanın olduğu görülmüștür [15].

\section{Materyal ve Metot}

$\mathrm{Bu}$ bölümde çalışmada kullanılan mikro-simülasyon ve sinyal optimizasyon programlarına, önerilen iş akış şemasına ve bu iş akış şemasının test edilmesi için seçilen kavşağa ait bilgiler detaylıca anlatılmıștır.

\subsection{Mikro-simülasyon ve sinyal optimizasyon programlarına ait bilgiler}

Çalışmada mikro-simülasyon programı olarak PTV Vissim v10 sürümünden faydalanılmıștır. $\mathrm{Bu}$ programın dünya genelinde 2500'den fazla şehirde ulaşım ve trafik analizlerinde kullanıldığı görülmektedir [16]. Ulaştırma ve trafik mühendisliğinde bu tür mikro-simülasyon programlarının kullanılması, yapılması planlanan yatırımların zor saha çalışmalarına gerek kalmadan test edilebilmesini mümkün hale getirmektedir. Bu durum ekonomik açıdan da yüksek fayda sağlamaktadır. Ayrıca mikro-simülasyon programına entegre bir sinyal optimizasyon programı kullanmak çalışmayı daha efektif bir hale getirmektedir. Bu doğrultuda çalışmada sinyal optimizasyon programı olarak PTV Vistro v6 sürümü kullanılmıștır. Bu programlar sayesinde kavşak performans çıtıları ile gerekli görülen düzenlemelerin kararı daha doğru verilebilirken, karar sürecinde de daha az efor ve zaman harcanmaktadır.

\section{2. Öneri iş akış şeması}

Bir kavşağın performansını analiz ederek artırmak için farklı uygulamalar bulunmaktadır. Bunların en başında öneri projelerinin gerçek hayatta uygulanmadan önce test edilebilmesini sağlayan, ekonomik ve iş gücü anlamında yüksek miktarda fayda getiren mikro-simülasyon programları gelmektedir. $\mathrm{Bu}$ programlar ile eşdüzey kavşaklarda düzenleme önerileri geliştirme süreci beş aşamalı bir iş akış şemasında ayrıntılı olarak anlatılmıştır (Şekil 1).

AŞAMA 1- Saha sayım ve gözlemlerinin yapılarak mikro-simülasyon girdilerinin hazırlanması: Mikrosimülasyon programları ile gerçek hayattaki girdiler ve veriler sanal ortama aktarlarak gerçek durumun bir modeli oluşturulabilmektedir. Bir eşdüzey kavşağın analizinde ve düzenleme önerilerinin geliştirilmesinde kullanılan girdiler ve veriler, kavşağın trafik hacimlerini ve yolların niceliksel bilgilerini gösteren unsurlardır. Trafik hacimleri saha çalışmalarında farklı yöntemler ile saptanabilmektedir. Video kamera tekniği ile gün içerisinde zirve saatlerde görüntüleri alınan kavşaktan geçen taşıtlar elle veya programlarla sayılarak sayısallaştırılmakta ya da yol çevresine monte edilen dedektörler yardımı ile trafik hacimleri belirlenebilmektedir. Ayrıca kavşağın her bir kolundan geçen taşıt sayıları türlerine göre sınıflandırılarak sayım föylerine not edilmekte ya da teknolojik yöntemlerle doğrudan belirlenmektedir.

AŞAMA 2- Mevcut durumdaki sorunların ve güvenlik problemlerinin tespit edilmesi: Gerek video kayıtlar izlenirken gerek sahada gözlem yapılırken tespit edilen mevcut durumdaki herhangi bir sorunun ya da standartlara uymayan tasarımsal hataların oluşturabileceği tehlikeleri ortadan kaldırmak için bu sorunların çözüm önerileri geliştirilme sürecinde göz önünde bulundurulması gerekmektedir.

AŞAMA 3- Mevcut durumun mikro-simülasyon programında modellenmesi, kalibrasyonu ve hizmet düzeyinin belirlenmesi: Mikro-simülasyon programına veri olarak girilmesi için en çok taşıtın geçtiği zaman diliminde (sabah, öğle, akşam) yer alan saatteki taşıt sayısı yani zirve saat değerini belirlemek gerekmektedir. Model oluşturulduktan sonra simülasyonun kavşağın gerçek hayattaki halini en doğru şekilde yansıtması için kalibrasyonu yapılmalıdır. Kalibrasyon sürecinde birçok yöntem kullanılabilmektedir. Bunlar simülasyon - gözlem değeri uygunluğu, Geoffrey E. Havers istatistiği (GEH), bağıl hata gibi yöntemlerdir [14].

Kalibrasyon tamamlandıktan sonra simülasyon artık gerçeği yansıtıyorsa mevcut durumun analizlerine başlanmaktadır ve kavşak performansında etkili olan ana parametreler ortalama gecikme, ortalama hiz, ortalama kuyruk uzunluğu, zararlı gaz emisyonu, yakıt tüketimi hesaplanmaktadır. $\mathrm{Bu}$ parametrelerden ortalama gecikme süresi ile eşdüzey kavşağın hizmet düzeyi belirlenebilmektedir. Ortalama gecikme süresi genel olarak Avustralya, Webster ya da HCM yöntemleri ile hesaplanabilmektedir. Ayrıca sinyalize ve sinyalize olmayan kavşaklarda hizmet düzeyini belirlemek için kullanılan ortalama gecikme sınır değerleri farklılık göstermektedir. 


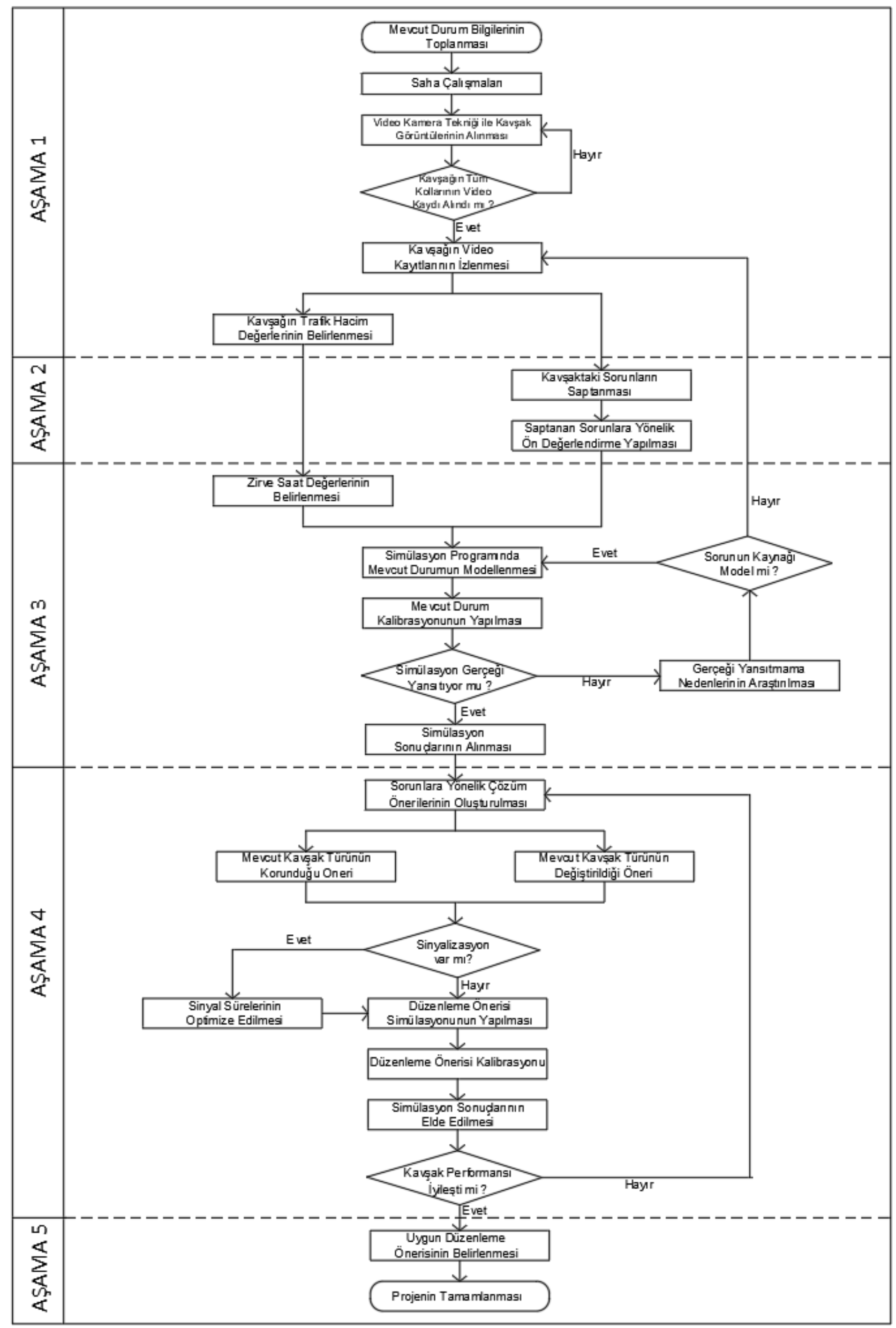

Şekil 1. Eşdüzey kavşak düzenlemeleri için önerilen iş akış şeması 
AŞAMA 4- Eşdüzey kavşak düzenleme önerilerinin geliştirilmesi: Mevcut durum analizleri yapıldıktan sonra eşdüzey kavşağın performansını ve hizmet düzeyini artırmak için kavşağın geometrisinde birtakım düzenlemeler yapılabilmektedir. Geometrik düzenlemeler ile mevcut kavşak türü korunabilmekte ya da değiştirilebilmektedir. Bu düzenleme çalışmaları esnasında Karayolları Genel Müdürlüğünün ilgili standartlarına uyulması gerekmektedir [17]. Bu konu ile ilgili yapılan çalışmalara bakıldığında geometrik düzenlemeler sonucu kavşakların performansında iyileşmeler olsa da bazı durumlarda sadece geometrik düzenlemelerden istenilen verimin alınamadı̆̆ görülmektedir. $\mathrm{Bu}$ gibi durumlarda sinyalizasyon sürelerini optimize etmek de söz konusu olmaktadır. Sinyal optimizasyonu birçok tekniğin yanı sıra bu işlevi gerçekleştiren bazı sinyal optimizasyon programları yardımıla da yapılabilmektedir. PTV Vistro, Synchro, Sidra vb. programlar bunlardan bazılarıdır. Bu programlarda da temel hedef trafik hacim değerlerini veri olarak programa işleyerek gecikme değerlerini ve optimum sinyal sürelerini saptamaktır.

AŞAMA 5- Uygun eşdüzey kavşak düzenleme önerisinin belirlenmesi: Hesaplanan sinyal sürelerinin ve yapılan geometrik düzenlemelerin kavşağın performansı üzerindeki etkisi Așama 3'te belirtilen performans parametre değerleri karşılaştırılarak analiz edilebilmektedir. Sunulan eşdüzey kavşak düzenleme önerileri mevcut durumla olduğu gibi kendi aralarında da karşılaştırılmalıdır. Karşılaştırılan performans parametrelerinin yanı sıra ekonomik açıdan da düşünüldüğünde en iyi koşulları sağlayan öneri belirlenmelidir.

\subsection{Seçilen kavşağa ait bilgiler}

Önerilen iş akış şemasının test edilmesi için öncelikle çalışma alanı içerisinde bir eşdüzey kavşak belirlenmiștir. Seçilen kavşak, Yalova ili merkez sınırları içerisindeki Termal yolu ile Şehit Ömer Faydalı caddesi ve Fatih caddesi kesişiminde bulunan Orman İşletme kavşağıdır. Bu kavşağın seçilmesindeki en önemli etken Yalova ilinin turistik ilçelerine gidenlerin bu kavşağı kullanmasıdır. Ayrıca Yalova Üniversitesi merkez yerleşkesine ulaşım Yalova merkezinden bu kavşak ile sağlanmaktadır. Bu sebeplerden dolayı Orman İşletme Kavşağı önemli bir konumdadır. Kavşağa ait uydu görüntüsü ve trafik akım yönleri Şekil 2'de verilmiştir. Orman İşletme kavşağı üç kollu sinyalize bir kavşaktır. Mevcut durumda kavşak 100 saniye devre süresi ile işletilmektedir. Bu kavşağın detaylı geometrik yapısı ve faz düzeni Şekil 3'te verilmiştir.

\section{Bulgular}

Eşdüzey kavşak düzenlemeleri için önerilen beş aşamalı iş akış şeması seçilen kavşakta test edilmiş ve elde edilen bulgular bu bölümde sunulmuştur.

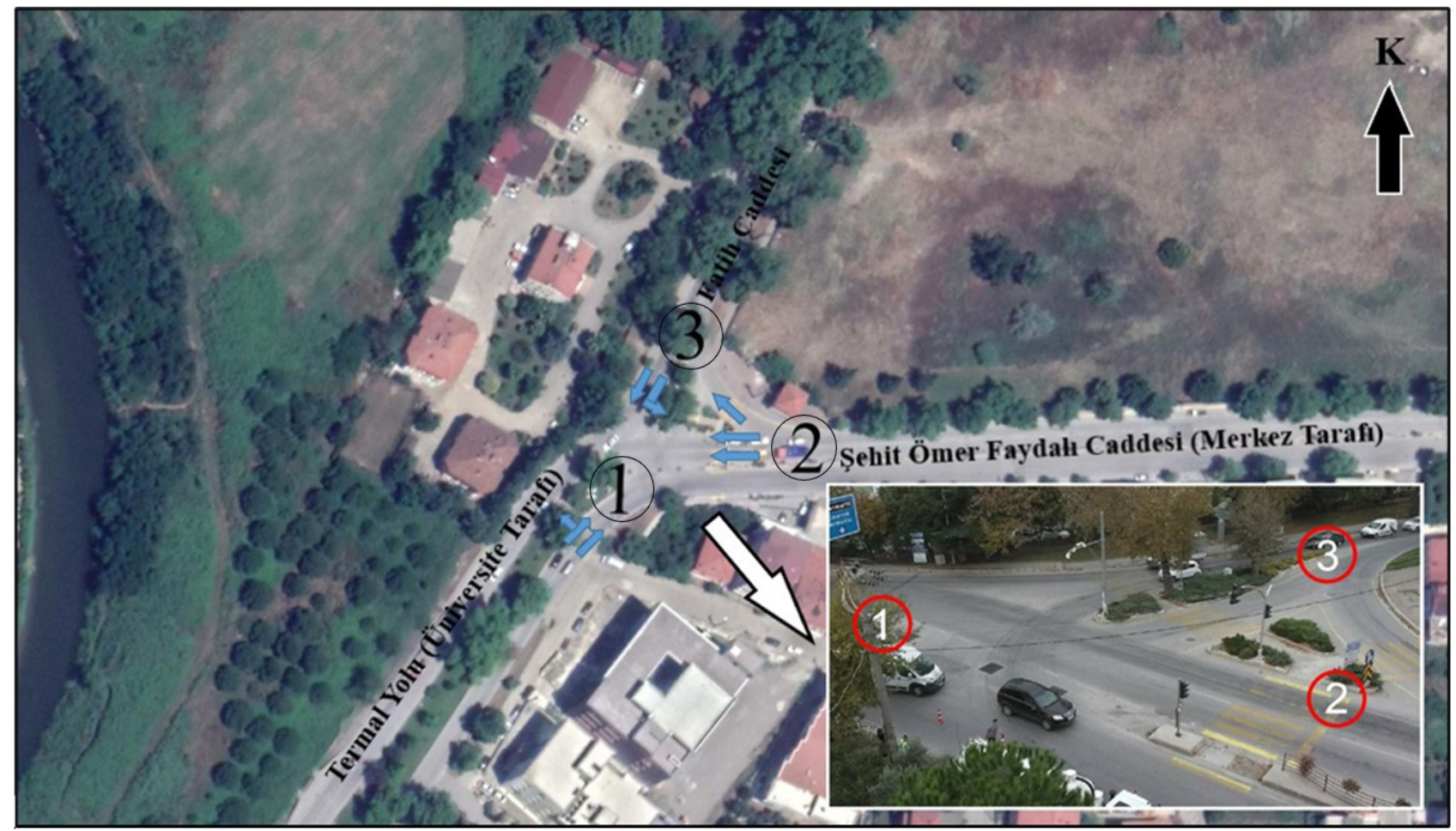

Şekil 2. Yalova Orman İşletme kavşağı uydu görüntüsü 


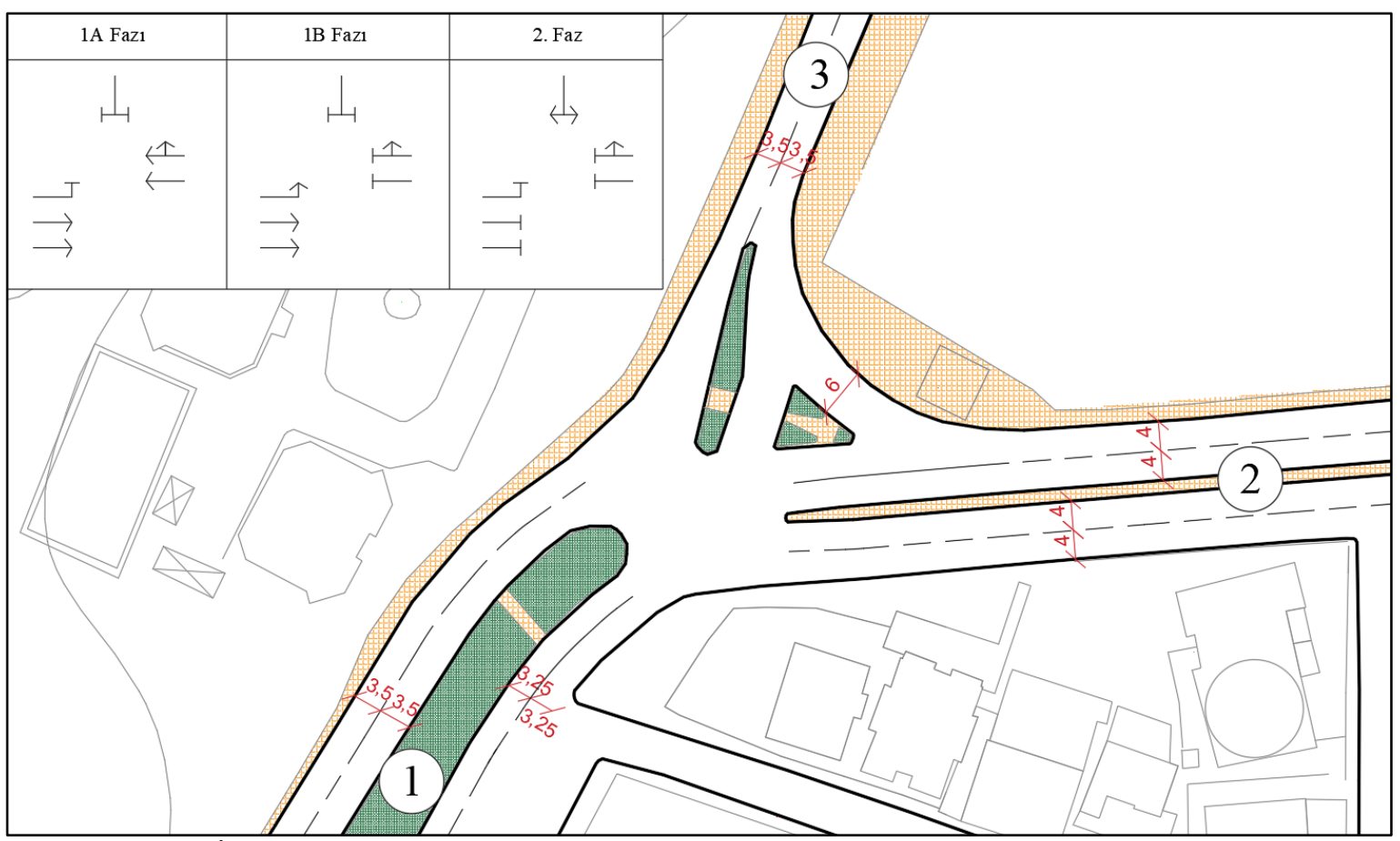

Şekil 3. Yalova Orman İşletme kavşağı mevcut durumu

\subsection{Saha sayım ve gözlemlerinin yapılarak mikro- simülasyon girdilerinin hazırlanması}

Eşdüzey kavşak düzenlemeleri için sunulan iş akış şemasının birinci aşamasıdır. Çalıșma sınırları belirlendikten sonra trafik sayımları ile ilgili veriler ve kavşağın mevcut durumundaki niceliksel değerleri (şerit genişliği, sinyal planları vb.) elde edilmektedir. $\mathrm{Bu}$ işlem gerek video kaydı gerek de diğer teknolojik işlemlerle yapılabilmekte olup amacı mikrosimülasyona girdi oluşturan verilerin belirlenmesidir. Buna göre, Orman İşletme kavşağının mevcut durumunun trafik hacim değerlerini, mevcut durumdaki yatay ve düşey işaretleme eksikliklerini, yanlış konumlandırılan sinyal direklerini, uygunsuz taşıt hareketlerini ve yapılan trafik ihlallerini saptamak için video kamera tekniği kullanılmıştır.

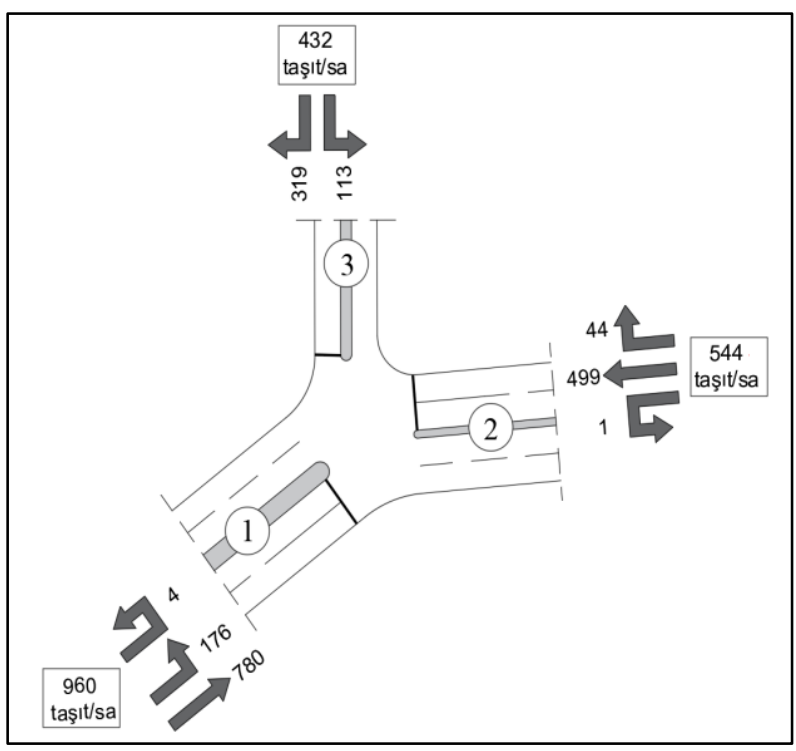

Şekil 4. Akım yönlerine göre gözlemlenen taşıt hacimleri
Bu kapsamda 5 Aralık Perşembe 2019 tarihinde sabah 07:00-09:00, öğle 12:00-14:00 ve akşam 17:00-19:00 saatlerinde kavşağın video kaydı alınmıştır. Eş zamanlı alınan kayıtlar için iki kişilik bir ekip kullanılmıştır.

Elde edilen video görüntüler izlenmeden önce üç kollu olan eşdüzey kavşağın her bir koluna numara verilmiştir. Böylece taşıt hareketleri daha iyi takip edilmektedir. Sonrasında video görüntüler izlenerek kavşağın trafik hacim değerleri saptanarak veri setine dönüştürülmüştür. Trafik hacimleri belirlenirken kavşağı kullanan taşıtlar türlerine (otomobil, taksi, kamyonet, otobüs, ağır taşıt vb.) göre de sınıflandırılmıştır. Trafik hacim değerleri belirlendikten sonra mikro-simülasyon programına girilecek zirve saat değerleri tüm akım kolları için hesaplanabilmektedir. Seçilen kavşakta en yüksek taşıt hacimleri akşam sayımında görülmüştür. $\mathrm{Bu}$ doğrultuda, zirve saat değeri belirlenmiş ve akım yönlerine göre taşıt hacimleri Şekil 4'te verilmiştir.

Zirve saat taşıt hacimlerinin akım kolu bazlı taşıt türleri Tablo 1'de verilmiştir.

Tablo 1. Taşıt türlerine göre zirve saat taşıt hacimleri

\begin{tabular}{ccccc}
\hline $\begin{array}{c}\text { Akım } \\
\text { Kolu }\end{array}$ & Otomobil & Ağır Taşıt & Otobüs & $\begin{array}{c}\text { Toplam } \\
\text { (taşıt/sa) }\end{array}$ \\
\hline 1 & 952 & 8 & - & 960 \\
2 & 534 & 5 & 5 & 544 \\
3 & 432 & - & - & 432 \\
Toplam & 1918 & 13 & 5 & 1936 \\
\hline
\end{tabular}

\subsection{Mevcut durumdaki sorunların ve güvenlik problemlerinin tespiti}

Eşdüzey kavşak düzenlemeleri için sunulan iş akış şemasının ikinci aşamasıdır. Kavşaklarda yapılan 
düzenlemelerin temel amacı kavşağın mevcut durumdaki sorunlarını çözmek ve kavşak performansını artırmaktır. Geliştirilen çözüm önerilerinde bu sorunların giderilmesine yönelik çalışmalar yapılmakta, ancak bunu gerçekleştirmek için öncelikle sorunların tespit edilmesi gerekmektedir. Bu amaçla Orman işletme kavşağının mevcut durumdaki sorunları ve güvenlik problemleri sahada yapılan gözlemler ve incelenen video görüntüler yardımıyla saptanmıştır. Buna göre:

- Durum 1: Yaya geçitleri sinyalizasyon direklerinin önüne yerleștirilmiş olup taşıtlar ișıkta dururken yaya geçitlerinin üzerinde beklemesi ve bu durumun yaya güvenliğini tehlikeye atması.

- Durum 2: Refüj ve trafik adalarının bitiş noktalarından yasak $u$ dönüşü ve uygunsuz hareketler yapılmasının tasarım eksikliklerinden dolayı müsait olması.

- Durum 3: Sola dönüş cebinin olmamasının düz giden akımı da etkilemesi ve kavşaktaki kuyrukların uzaması.

- Durum 4: Kavşak içi geçişlerde iki şeritten tek şeride düşüşler nedeniyle darboğaz oluşması.

Bahsedilen dört duruma ait görseller Şekil 5'te verilmiştir.

\subsection{Mevcut durumun mikro-simülasyon programinda modellenmesi, kalibrasyonu ve hizmet düzeyinin belirlenmesi}

Eşdüzey kavşak düzenlemeleri için sunulan iş akış şemasının üçüncü aşamasıdır. Mikro-simülasyon girdilerinin tamamı hazır hale geldikten sonra kavşağın mevcut durum simülasyonu modellenmelidir. Sonrasında simülasyon modelinin kalibrasyonu yapılarak kavşağın mevcut durumdaki performans parametrelerinin değerleri elde edilmektedir. $\mathrm{Bu}$ doğrultuda, Orman İşletme kavşağının zirve saat değerlerini simülasyon programına girmeden önce kavşağın mevcut durumdaki geometrisi PTV Vissim mikro-simülasyon programında uygun şekilde modellenmiştir. Gerçek durumu birebir yansıtması için yaya yolları, binalar ve kavşak çevresindeki her bir detay mikro-simülasyon programına aktarılmıştır. Ardından zirve saat değerleri ve mevcut durumdaki sinyal süreleri programa işlenip modelin kalibrasyonu gerçekleştirilmiştir. Kalibrasyonlar, simülasyon ile gözlenen taşıt sayısı uygunluğu bazında yapılmıştır. Eşdüzey kavşağa ait mevcut durum simülasyon görüntüleri Şekil 6'da verilmiştir.

Mevcut durum analizi kavşağın taşıtlar tarafindan kullanımının daha yüksek olduğu akşam zirve saati için gerçekleştirilmiştir. Analizler sonucu kavşakta; ortalama gecikme, ortalama hız, ortalama kuyruk uzunluğu, zararlı gaz emisyonu ve yakıt tüketimi parametrelerinin değerleri elde edilmiştir. Eşdüzey kavşağın mevcut durumdaki hizmet düzeyinin ortalama gecikme süresine bakıldığında 27,6 saniye ile $\mathrm{C}$ olduğu belirlenmiştir. Orman İşletme kavşağının mevcut durumuna ait simülasyon sonuçları Tablo 2'de verilmiştir.

\subsection{Eşdüzey kavşak düzenleme önerilerinin geliş̧irilmesi}

Eşdüzey kavșak düzenlemeleri için sunulan iș akıș şemasının dördüncü aşamasıdır. Bu aşamada, eşdüzey kavşaklarda düzenleme önerilerinin geliștirilmesi süreci ikiye ayrılmıştır. İlkinde, mevcut kavşak türü korunarak maliyeti düşük tutmak amaçlanmaktadır. İkincisinde, sağlanan faydanın talep edilen ihtiyacı karşılamadığı durumlarda, mevcut kavşak türü değiştirilmekte ve farklı geometrik tasarımlar uygulanmaktadır. Bu doğrultuda, Orman İşletme kavşağının mevcut durumda tespit edilen sorunlarını çözmek, kavşağın hizmet düzeyini yükseltmek ve kavşağın performans parametrelerini iyileştirmek için iki farklı öneri geliştirilmiştir.

\subsection{1. Öneri 1: Mevcut kavşak türünün korunduğu öneri}

Dördüncü aşama kapsamında yapılan kavşak düzenleme önerisinin ilkidir. Bu öneride kavşağın mevcut geometrisi genel olarak korunmuş olup ikinci aşamada belirtilen sola dönen taşıtların kavşakta kuyruk yapmaması için Termal tarafindan (2) gelerek Fatih caddesine (3) giden trafik akımına sola dönüş cebi tasarlanmıştır. Sola dönüș cebi uzunluğu, Poisson dağılımına göre \%85 güven aralığında tașıt boyunun 5 metre olarak kabul edilmesiyle 40 metre olarak hesaplanmıştır. Diğer bir düzenleme ise Fatih caddesinden (3) gelerek Termal tarafına (2) giden trafik akımına kontrollü geçiş uygulanmasıdır. Ayrıca darboğaz olan yol kesimlerinde (3) şerit sayısı teke düşürülerek şerit genişliği artırılmıştır. Geometrik düzenlemelerde Karayolları Tasarım El Kitabındaki standartlara uyulmuștur [17]. Mevcut kavșak türünün korunduğu öneriye ait trafik akım kolları, faz düzeni, sinyal planlaması ve yeşil süreler Şekil 7'de verilmiştir.

İlk öneride, geometrik düzenlemelerin yanı sıra kavşağın mevcut durumdaki sinyal süreleri de optimize edilmiştir. Sinyal sürelerinin optimizasyonu için PTV Vistro programı kullanılmıştır. Mikrosimülasyon programında olduğu gibi sinyal optimizasyon programında da kavşak geometrisi tasarlanmış, akşam zirve saat taşıt hacim değerleri programa girilmiştir. PTV Vistro programı sinyal optimizasyonun HCM 2010 yöntemi çerçevesinde gerçekleştirip yeni sinyal süreleri belirlenmiştir [18]. Kavşak geometrisine göre sarı süre 3 saniye, ortak kırmızı süre 1 saniye girilmiş olup, devre süresi 60 saniye olarak hesaplanmıştır. Kavşağın sinyal 
optimizasyonu tamamlandıktan sonra ilgili önerinin analizini yapmak için PTV Vissim mikro-simülasyon programında kavşağın düzenlenmiş geometrisi modellenmiş ve optimize edilmiş sinyal süreleri programa girilmiştir. Sonrasında model kalibre edilerek simülasyon doğrulanmıştır. İlk önerinin simülasyon görüntüleri Şekil 8'de verilmiştir.

Mikro-simülasyon sonuçlarına göre ilk öneri ile kavşağın hizmet düzeyi A'ya çıkmıştır. Ortalama gecikme süresi 8,7 saniyeye gerilemiş, ortalama hız $36,2 \mathrm{~km} /$ sa'e yükselmiştir. Ortalama kuyruk uzunluğu ise 2 metre olarak belirlenmiştir. Doğaya salınan zararlı gaz emisyonlarında (CO ve NOX) ve yakıt tüketiminde de ciddi azalmalar meydana gelmiştir.

\subsection{2. Öneri 2: Mevcut kavşak türünün değiştirildiği öneri}

Dördüncü aşama kapsamında yapılan kavşak düzenleme önerisinin ikincisidir. Bu öneri, Orman İşletme kavşağının mevcut durumda tespit edilen sorunlarını çözmek, kavşağın hizmet düzeyini yükseltmek ve kavşağın performans parametrelerini iyileştirmek için sunulmuştur. İkinci öneride kavşak türü değiştirilmiş, üç kollu dönel kavşak tasarımı uygulanmıştır. Dönel ada çapı 14 metre, dönel kavşak içerisindeki şerit genişlikleri ise 3,5 metre olarak tasarlanmıştır. Dönel kavşak tasarımı yapılırken Karayolları Tasarımı El Kitabındaki dönel kavşaklar ile ilgili standartlara uyulmuştur [17]. Mevcut kavşak türünün değiştirildiği öneri Şekil 9'da verilmiştir.
Orman İşletme kavşağı için sunulan ikinci önerinin analizlerini yapmak amaciyla dönel kavşak geometrisi mikro-simülasyon programında modellenerek akşam zirve saat değerleri programa girilmiş ve sonrasında model kalibre edilmiştir. İkinci önerinin simülasyon görüntüleri Şekil 10'da verilmiştir. Mikro-simülasyon sonuçlarına göre ikinci öneri ile kavşağın hizmet düzeyi A'ya çıkmıştır. Ortalama gecikme süresi 4,3 saniyeye düșerken, ortalama hı $40,4 \mathrm{~km} / \mathrm{sa}$ 'e yükselmiştir. Ortalama kuyruk uzunluğu 1,1 metreye kadar azalmıștır. Doğaya salınan zararlı gaz emisyonlarında (CO ve NOX) ve yakıt tüketiminde ise önemli derecede düşüşler görülmüştür.

\subsection{Uygun eşdüzey kavşak düzenleme önerisinin belirlenmesi}

Eşdüzey kavşak düzenlemeleri için sunulan iş akış şemasının beşinci ve son aşamasıdır. Kavşak düzenlemelerindeki temel amaç daha önceden de belirtildiği gibi kavşağın sorunlarını çözmek ve performansını artırmaktır. Bu doğrultuda, geliştirilen kavşak düzenleme önerilerinin mevcut durumdaki sorunlara ne düzeyde cevap verdiği irdelenmelidir. Sonrasında, bu önerilerin sağladığı faydalar ile yapım, işletme ve bakım maliyetleri karşılaştırılarak seçim yapılmaktadır. Mikro-simülasyon programı analiz çıktıları ile sağlanan faydalar sunulmaktadır. Bu doğrultuda Orman İșletme kavşağının mevcut durumu ve geliştirilen önerilere ait simülasyon sonuçları Tablo 3'te gösterilmiștir.

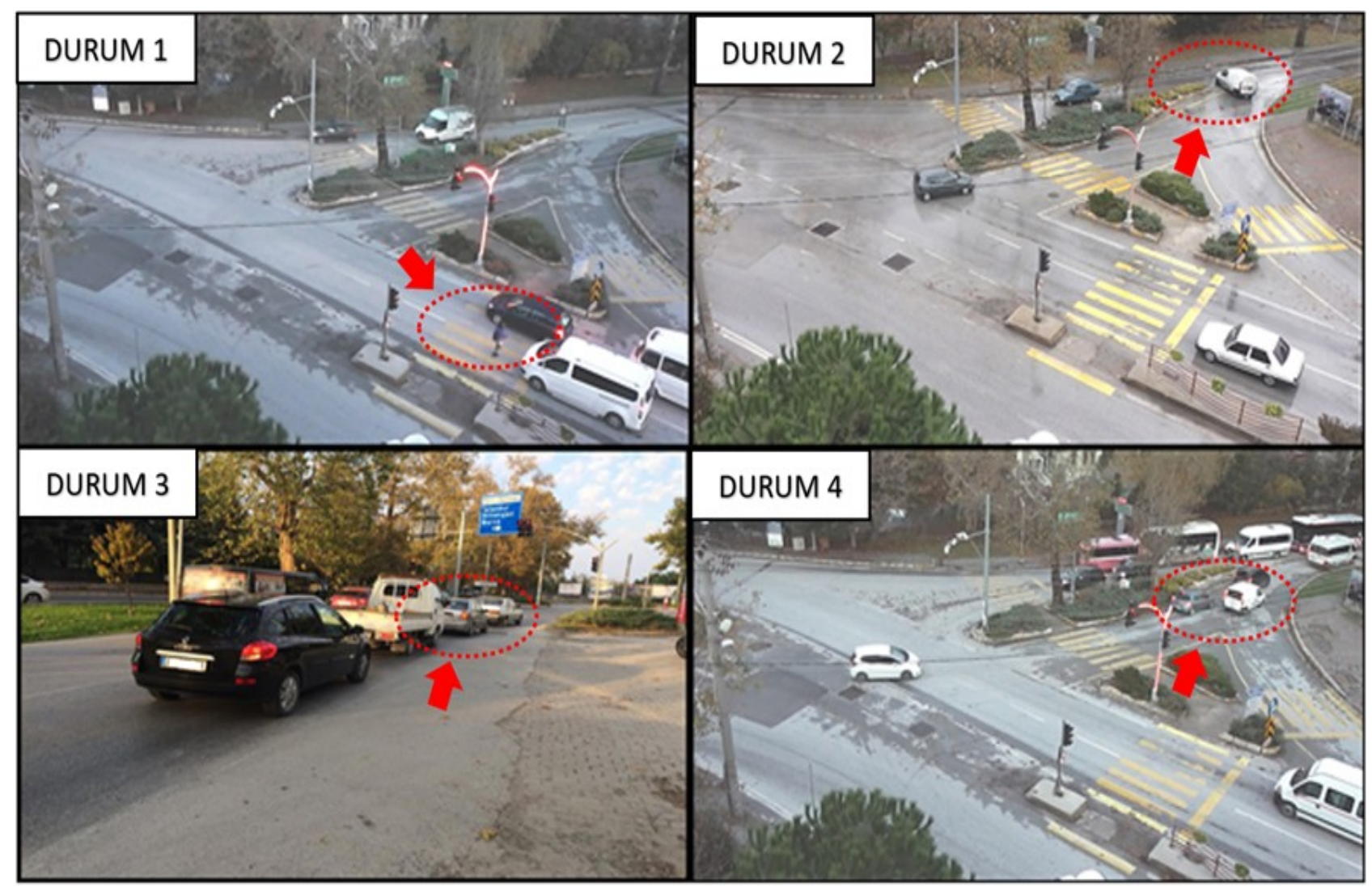

Şekil 5. Eşdüzey kavşakta tespit edilen sorunlar 


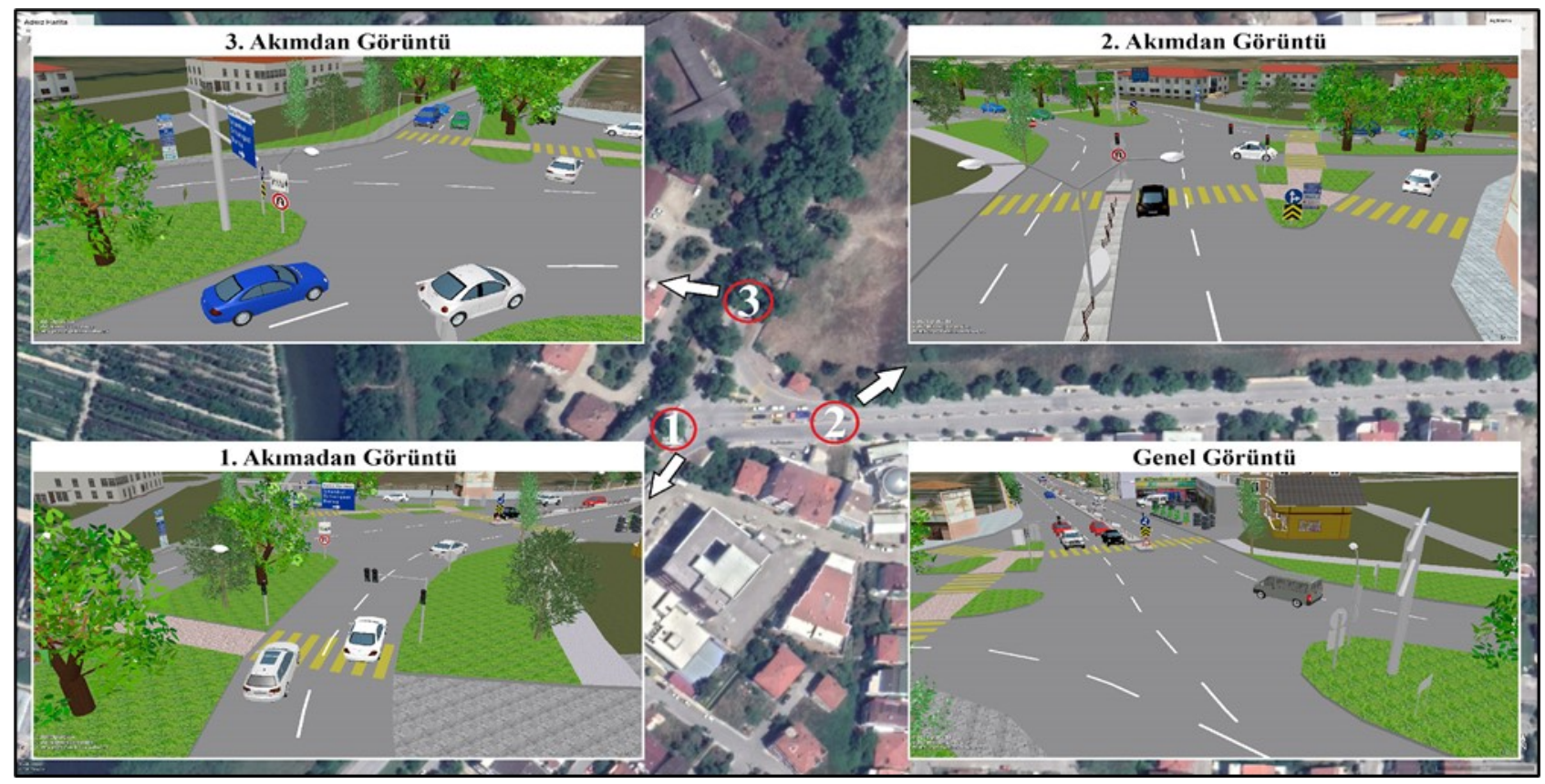

Şekil 6. Eşdüzey kavşağın mevcut durum simülasyon görüntüleri

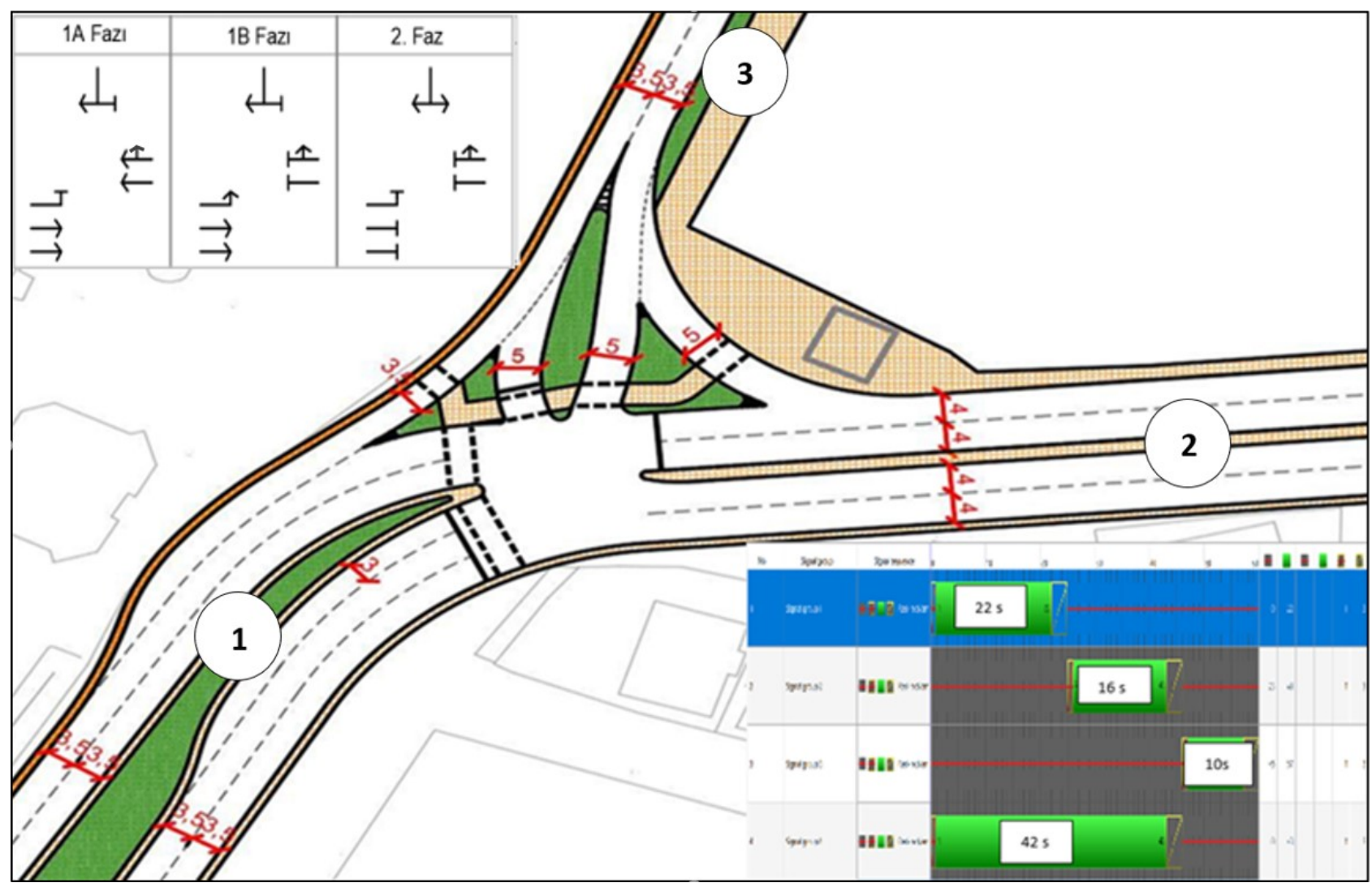

Şekil 7. Öneri 1: Mevcut kavşak türünün korunduğu öneri

Tablo 2. Mevcut durum simülasyon sonuçları

\begin{tabular}{cccccccc}
\hline & $\begin{array}{c}\text { Hizmet } \\
\text { Düzeyi }\end{array}$ & $\begin{array}{c}\text { Ortalama } \\
\text { Gecikme (s) }\end{array}$ & $\begin{array}{c}\text { Ortalama } \\
\text { Hız (km/sa) }\end{array}$ & $\begin{array}{c}\text { Ortalama } \\
\text { Kuyruk } \\
\text { Uzunluğ (m) }\end{array}$ & $\begin{array}{c}\text { Zararlı Gaz } \\
\text { Emisyonu } \\
\text { Co (gr) }\end{array}$ & $\begin{array}{c}\text { Zararlı Gaz } \\
\text { Emisyonu } \\
\text { NoX (gr) }\end{array}$ & $\begin{array}{c}\text { Yakit } \\
\text { Tüketimi } \\
\text { (galon) }\end{array}$ \\
\hline $\begin{array}{c}\text { Mevcut } \\
\text { Durum }\end{array}$ & $\mathrm{C}$ & 27,6 & 25,5 & 15,8 & 2186,4 & 425,4 & 31,3 \\
\hline
\end{tabular}




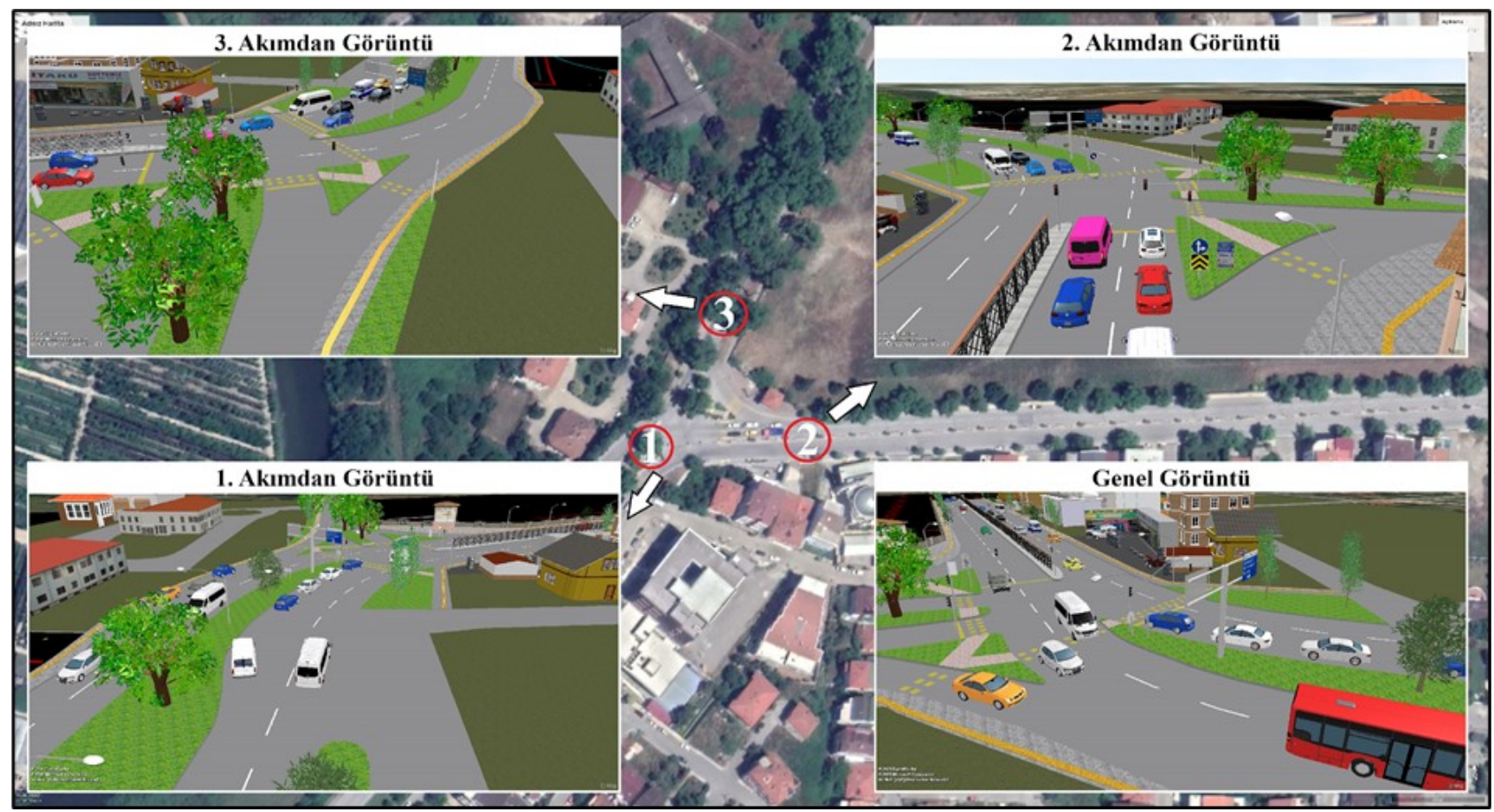

Şekil 8. Öneri 1: Mevcut kavşak türünün korunduğu önerinin simülasyon görüntüleri

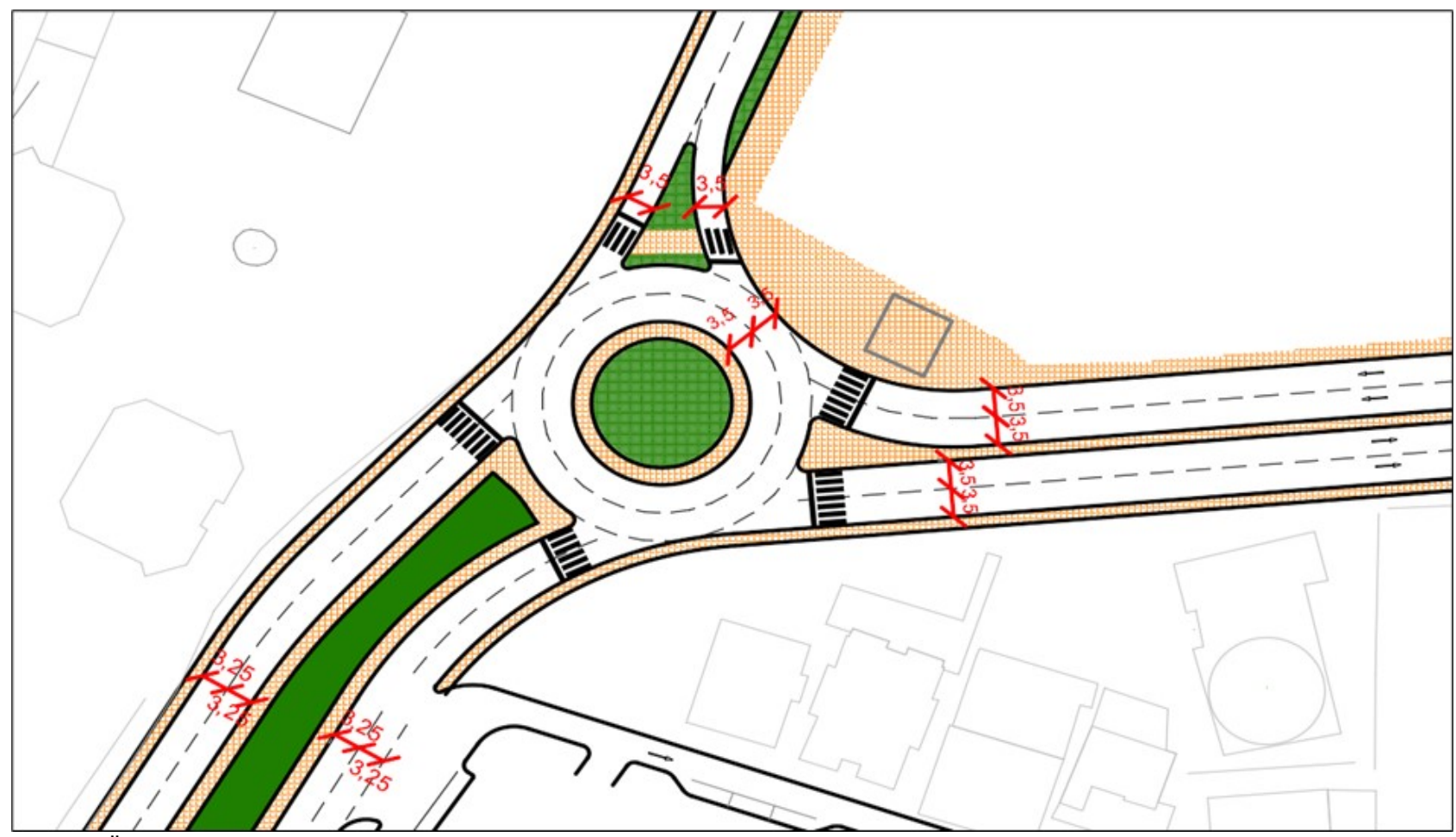

Şekil 9. Öneri 2: Mevcut kavşak türünün değiștirildiği öneri

Tablo 3. Mevcut durum ve önerilere ait simülasyon sonuçları

\begin{tabular}{lccccccc}
\hline & $\begin{array}{c}\text { Hizmet } \\
\text { Düzeyi }\end{array}$ & $\begin{array}{c}\text { Ortalama } \\
\text { Gecikme (s) }\end{array}$ & $\begin{array}{c}\text { Ortalama } \\
\text { Hız (km/sa) }\end{array}$ & $\begin{array}{c}\text { Ortalama } \\
\text { Kuyruk } \\
\text { Uzunluğu (m) }\end{array}$ & $\begin{array}{c}\text { Zararlı Gaz } \\
\text { Emisyonu } \\
\text { Co (gr) }\end{array}$ & $\begin{array}{c}\text { Zararlı Gaz } \\
\text { Emisyonu } \\
\text { NOX (gr) }\end{array}$ & $\begin{array}{c}\text { Yakıt } \\
\text { Tüketimi } \\
\text { (galon) }\end{array}$ \\
\hline $\begin{array}{l}\text { Mevcut } \\
\text { Durum }\end{array}$ & $\mathrm{C}$ & 27,6 & 25,5 & 15,8 & 2186,4 & 425,4 & 31,3 \\
Öneri 1 & $\mathrm{A}$ & 8,7 & 36,2 & 2,0 & 1249,6 & 243,1 & 17,9 \\
Öneri 2 & $\mathrm{A}$ & 4,3 & 40,4 & 1,1 & 926,0 & 180,2 & 13,2 \\
\hline
\end{tabular}




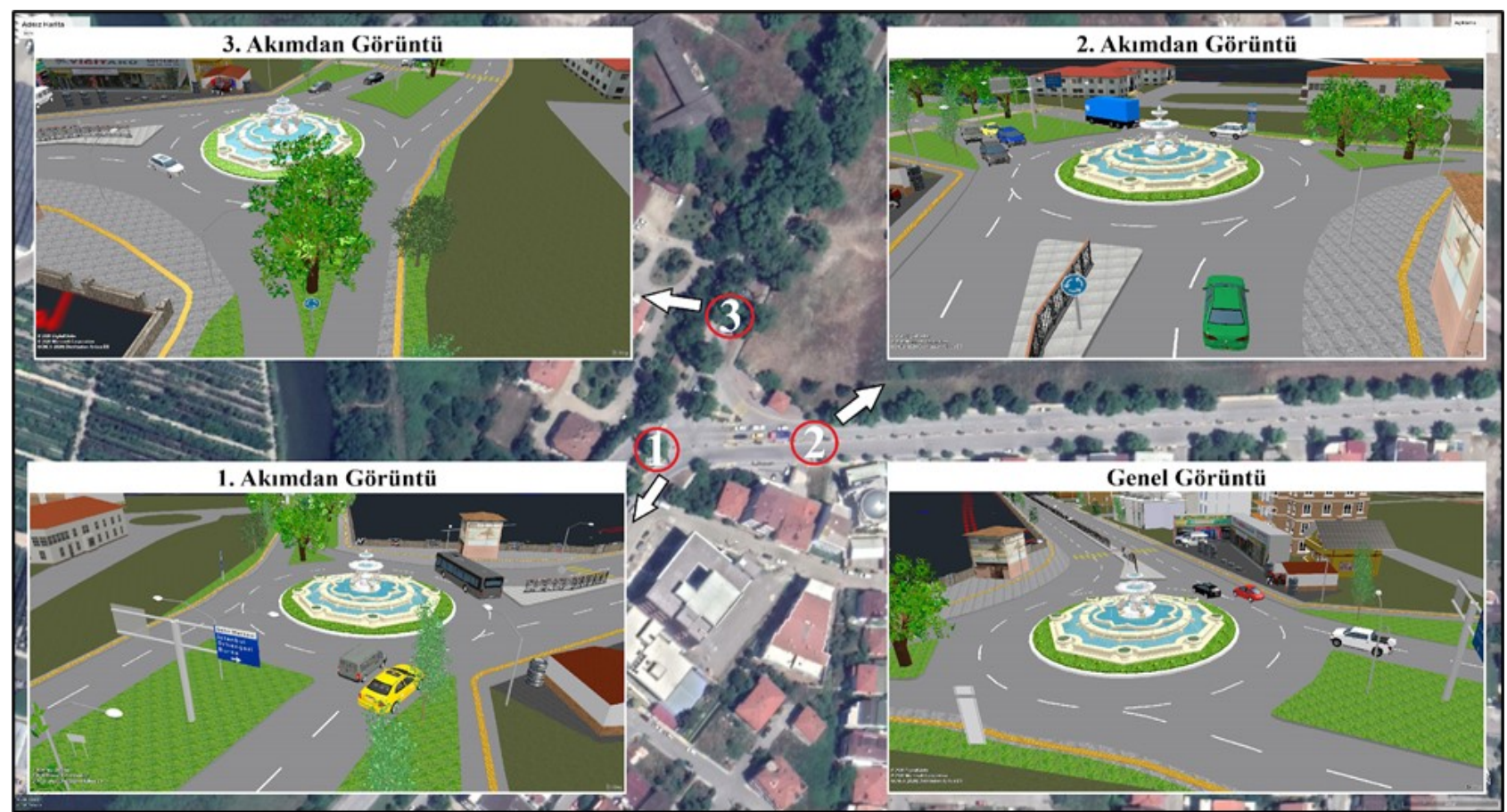

Şekil 10. Öneri 2: Mevcut kavşak türünün değiștirildiği önerinin simülasyon görüntüleri

Analiz sonuçlarına göre ilk öneri ile mevcut durum karşılaștırıldığında;

- Kavşağın hizmet düzeyinin A'ya yükseldiği,

- Ortalama gecikme süresinin \%68 azaldığı,

- Ortalama hızın \%42 arttığı,

- Ortalama kuyruk uzunluğunun \%87 azaldığı,

- Karbonmonoksit (CO), Nitrik oksit (NOX) salınımının ve yakıt tüketiminin \%43 azaldığı

görülmüştür. İkinci öneri ile diğer durumlar karşılaştırıldığında ise;

- Kavşağın hizmet düzeyinin A'ya yükseldiği,

- Ortalama gecikme süresinin ilk öneriye göre $\% 51$, mevcut duruma göre $\% 84$ azaldığ

- Ortalama hızın ilk öneriye göre $\% 12$, mevcut duruma göre \%58 arttığl,

- Ortalama kuyruk uzunluğunun ilk öneriye göre $\% 45$, mevcut duruma göre \%93 azaldığı,

- Karbonmonoksit (CO), Nitrik oksit (NOX) salınımının ve yakıt tüketiminin ilk öneriye göre $\% 26$, mevcut duruma göre $\% 58$ azaldığı

belirlenmiştir. Geometrik düzenleme açısından ikinci önerideki kavşak türü değişikliğinin yapım maliyetini artıracağı, sinyalizasyon sisteminin kaldırılmasının ise işletme ve bakım maliyetini düşüreceği öngörülmektedir. Buna göre, performans kriterleri karşılaştırılırken mutlaka ekonomik kısıtlar da dikkate alınmalıdır. Çalışma kapsamında, sadece kavşak performans iyileştirmelerine ait sonuçlar dikkate alınmıştır. Bu açıdan analiz sonuçlarına bakıldığında kavşak performansının iyileştirilmesi açısından ikinci önerinin seçilmesi daha uygun görülmektedir.

\section{Tartışma ve Sonuç}

Mikro-simülasyon programlarının kullanılması ile ulaşım sorunlarını çözerek ulaşım performansını değerlendirmek kolaylaşmıştır. Özellikle kavşak düzenlemelerinde kullanılan mikro-simülasyon programları birçok açıdan önemli faydalar sağladığı için bu programların kullanıldığı çalışmaların sayısı giderek artmaktadır. Bu doğrultuda, çalışmada eşdüzey kavşaklarda düzenleme önerileri geliştirmek için bir iş akış şeması önerilmiştir. Sunulan iş akış șemasındaki adımlar doğru ve uygun şekilde yapıldığında, bir eşdüzey kavşağın sorunlarını tespit ederek bu sorunları çözmek ve kavşağın performansını artırmak mümkün ve daha kolay hale gelmektedir.

İş akış şemasını test etmek için saha çalışması kapsamında Yalova ili sınırları içerisinde bulunan Orman İşletme kavşağı seçilmiștir. Çalışma ile kavşağın mevcut durumdaki sorunlarını çözmek ve performansını artırmak hedeflenmiștir. Saha çalışmaları yapılmış ve mikro-simülasyon programı kullanılarak mevcut kavşak türünün korunduğu ve mevcut kavşak türünün değiştirildiği iki farklı kavşak düzenleme önerisi sunulmuștur. Sunulan ilk öneride geometrik düzenlemelerin yanı sıra sinyal optimizasyon programı yardımıyla kavşağın sinyal süreleri de optimize edilmiştir. İlk öneride mevcut duruma göre ortalama gecikme süresinde $\% 68$, ortalama kuyruk uzunluğunda $\% 87$ oranında azalma; ortalama hizda ise \%42 oranında artma gözlenmiştir. Doğaya salınan zararlı gazlara (CO ve NOX) ve tüketilen yakıt miktarına bakıldığında ise her biri için \%43 oranında azalma olduğu görülmüștür. Sunulan ikinci öneride ise Orman 
İşletme kavşağının mevcut geometrisi tamamen değiştirilmiş ve 3 kollu dönel kavşak tasarlanarak sinyalizasyon sistemi kaldırılmıştır. Bu öneride ise mevcut duruma göre ortalama gecikme süresinde $\% 84$ ve ortalama kuyruk uzunluğunda \%93 oranında azalma gözlenmiştir. Ortalama hızda ise \%58 oranında artma görülmüştür. Doğaya salınan zararlı gazlarda (CO-NOX) ve yakıt tüketiminde \%58 oranında iyileşme elde edilmiştir. Kavşak performansı açısından en uygun çözümün ikinci öneri olduğuna karar verilmiștir.

Eşdüzey kavşaklarda yapılan çalışmalarda mikrosimülasyon programları kullanılmakta, fakat bu çalışmaların bazılarının belirli bir düzene göre yapılmadığı görülmektedir. $\mathrm{Bu}$ doğrultuda, çalışmada verilen iş akış şemasının eşdüzey kavşak düzenleme önerilerini geliştirme sürecinde kullanılması fayda sağlayacaktır. Ayrıca ilerleyen çalışmalarda, araştırmacıların sunulan iş akış şeması üzerine eklemeler (kavşak türlerine göre ayrım, ekonomik karşılaştırma vb.) yapmaları katkı düzeyini artıracaktır.

\section{Teşekkür}

2019-2020 eğitim öğretim yılında, Yalova Üniversitesi, Ulaştırma Mühendisliği bölümünde lisans bitirme tezi olarak yapılan 'Yalova Orman İşletme Kavşağının Düzenleme Önerileri ve Simülasyon Analizleri' bu makalenin içeriğini oluşturmaktadır. Bu kapsamda çalışma sürecinde PTV Group tarafindan sağlanan Vissim ve Vistro programları kullanılmıştır. PTV Vissim mikrosimülasyon ve PTV Vistro sinyal optimizasyon programlarının lisansları 08.01.2020 - 06.07.2020 tarihleri arasında sağlanmıştır. Bundan dolayı, bu çalışmaya katkıda bulundukları için PTV Group'a teşekkür ederiz.

Yalova Belediyesi, Ulaşım Hizmetleri Müdürlüğünden ilgili kavşağa ait hali hazır haritalar ve sinyal planları temin edilmiștir. Çalıșmaya verdikleri destekler için Yalova Belediyesi, Ulaşım Hizmetleri Müdürlügüu'ne teşekkür ederiz.

\section{Etik Beyanı}

Bu çalışmada, "Yükseköğretim Kurumları Bilimsel Araştırma ve Yayın Etiği Yönergesi” kapsamında uyulması gerekli tüm kurallara uyulduğunu, bahsi geçen yönergenin "Bilimsel Araştırma ve Yayın Etiğine Aykırı Eylemler" başlı̆̆ı altında belirtilen eylemlerden hiçbirinin gerçekleștirilmediğini taahhüt ederiz.

\section{Kaynakça}

[1] Türkiye İstatistik Kurumu (TÜİK). 2021. Trafiğe Kayıtlı Motorlu Kara Taşıt Sayısı. https://data.tuik.gov.tr (Erişim Tarihi: 10.05.2021).
[2] Lejri, D., Can, A., Schipre, N. and Leclercq, L. 2018. Accounting for Traffic Speed Dynamics when Calculating COPERT and PHEM Pollutant Emissions at the Urban Scale. Transportation Research Part D: Transport and Environment, 63, 588-603.

[3] Kotusevski, G., Hawick, K.A. 2009. A Review of Traffic Simulation Software. Research Letters in the Information and Mathematical Sciences, 13, 35-54.

[4] Park, B., Schneeberger, J.D. 2003. Microscopic Simulation Model Calibration and Validation: Case Study of VISSIM Simulation Model for a Coordinated Actuated Signal System. Transportation Research Record: Journal of the Transportation Research Board, 1856(1), 185192.

[5] Bloomberg, L., Dale, J. 2000. Comparison of VISSIM and CORSIM Traffic Simulation Models on a Congested Network. Transportation Research Record: Journal of the Transportation Research Board, 1727(1), 52-60.

[6] Akmaz, M. M. 2012. Konya'nın önemli sinyalize kavşaklarının bilgisayar programı ile incelenmesi. Selçuk Üniversitesi, Fen Bilimleri Enstitüsü, Yüksek Lisans Tezi, 103s, Konya.

[7] Zeydan, Ö., Polat, M., Bayık, G. D., Tanış, M. 2017. Sidra Intersection Programı ile Kavşak İyileştirmesinin Taşıt Emisyon Miktarlarına Etkisi: Zonguldak Örneği, VII. Ulusal Hava Kirliliği ve Kontrolü Sempozyumu, 1-3 Kasım, Antalya, 438-449.

[8] Naghawi, H., Alsoud, A., Alhadidi, T. 2018. The Possibility for Implementing the Superstreet Unconventional Intersection Design in Jordan. Periodica Polytechnica Transportation Engineering, 46(3), 122-128.

[9] Bayata, H. F., Bayrak, O. Ü. 2018. Yeni Yapılması Planlanan Bir Kavşağın Mikro-Simülasyon ile Değerlendirilmesi. Erzincan Üniversitesi Fen Bilimleri Enstitüsü Dergisi, 11(3), 550-559.

[10] Erol, D. 2018. Kent içi ışıklı ve dönel kavşak uygulamalarının performans kriterlerine etkisi: Denizli örneği. Pamukkale Üniversitesi Fen Bilimleri Enstitüsü, Yüksek Lisans Tezi, 89s, Denizli.

[11] Zainuddin, N. I., Shah, S. M. R., Hashim, M. Z., Roslam, M. S., Tey, L. S. 2018. Comparison of Operational Performance Before and After Improvement: Case Study at Pengkalan Weld, Pulau Pinang, AIP Conference Proceedings, 2020(1), 020027(1) - 020027(8).

[12] Ziboon, A. R. T., Qasim, Z. I., Yousif, M. A. 2019. Traffic Performance Evaluation and Analysis of Al-Fallah Intersection in Baghdad City Utilizing Synchro 10 Software. Journal of Engineering and Sustainable Development, 23(06), 25-34. 
[13] Muchlisin, I. T., Widodo, W. 2019. Optimization Model of Unsignalized Intersection to Signalized Intersection Using PTV Vissim: Study Case in Imogiri Barat and Tritunggal Intersection, Yogyakarta, Indonesia. International Journal of Integrated Engineering, 11(9), 11-25.

[14] Baș, F. İ., Çolak, M. A., Demiriz, A. O., Bayata, H. F., Bayrak, O. Ü., Keleş, Ö. F., Mazlum, Y., Gürel, M. O., Demircioğlu, M. S. 2020. Kent içi Kavşakların Mikro-Simülasyon Yöntemiyle Modellenmesi: Erzurum İli Örneği. Avrupa Bilim ve Teknoloji Dergisi, Özel Sayı, 444-451.
[15] Fabianova, J., Michalik, P., Janekova, J., Fabian, M. 2020. Design and Evaluation of a New Intersection Model to Minimize Congestions using VISSIM Software. Open Engineering, 10(1), 48-56.

[16] https://your.vissim.ptvgroup.com/comparison -software-for-traffic-simulation (Erișim Tarihi: 07.09.2021).

[17] KGM, 2005. Karayolu tasarım el kitabı. Karayolları Genel Müdürlüğü, 297s.

[18] National Research Council, 2010. Highway capacity manual 2010. 5th ed., Transportation Research Board, Washington, D.C. 